\title{
Climate trends in the Cape Town area, South Africa
}

\author{
Mark R Jury ${ }^{1,2}$ \\ 'Geography Dept, University of Zululand, KwaDlangewa, South Africa \\ ${ }^{2}$ Physics Dept, University of Puerto Rico Mayagüez, Mayagüez, USA
}

Climatic conditions near Cape Town, South Africa $\left(34^{\circ} \mathrm{S}, 19^{\circ} \mathrm{E}\right)$ are analysed for historical trends in station measurements in the $20^{\text {th }}$ century and in modern satellite-blended datasets. Despite the variety of datasets and record lengths, all show a steady drying trend. Faster rates of warming, $0.1^{\circ} \mathrm{C} \cdot \mathrm{yr} \mathrm{r}^{1}$, are found in land surface temperatures during the period 2000-2017. Drying trends are most acute to the northwest of the Hottentots Holland mountains. Hydrology station measurements in the Upper Berg River catchment since 1956 reveal a decline in streamflow of $-0.012 \mathrm{~m}^{3} \cdot \mathrm{s}^{-1} \cdot \mathrm{month}^{-1}$, and an upward slope in potential evaporation of $+0.020 \mathrm{~W} \cdot \mathrm{m}^{-2}$ . month $^{-1}$. Rainfall has declined most in May and September, indicating a shorter winter wet season. Features supporting the drying trend include an increase of easterly winds and low-level subsidence during summer. The clockwise circulation trend around Cape Town entrains dry air from the Karoo interior and the south coast upwelling zone, leading to negative sensible heat flux, a capping inversion and diminished orographic rainfall.

\section{INTRODUCTION}

The southwestern (SW) Cape of South Africa $\left(34^{\circ} \mathrm{S}, 19^{\circ} \mathrm{E}\right)$ lies at the transition between the subtropical easterly and mid-latitude westerly wind regimes, and has a semi-arid, rainy-winter climate. The adjacent interior (Karoo) has sparse vegetation fronted by coastal mountains over $1000 \mathrm{~m}$. Past research on climate change at country-scale has found $\mathrm{a} \sim 0.02^{\circ} \mathrm{C} \cdot \mathrm{yr}^{-1}$ increase of temperature (Kruger and Shongwe, 2004; Morishima and Akasaka, 2010; Kruger and Nxumalo, 2016) consistent with global averages, and mixed trends in rainfall (Tadross et al., 2005; MacKellar et al., 2014). Yet, water resources within reach of Cape Town's 4 million people (west of $20^{\circ} \mathrm{E}$ ) dwindled to $<30 \%$ of storage capacity according to the Department of Water and Sanitation (DWS), at the time of conducting this research in 2018. The scarcity of water supplies initiated numerous engineering projects (Muller, 2017), and rationing of $50 \mathrm{~L}^{1} \cdot$ day $^{-1}$. person ${ }^{-1}$. Here an analysis of meteorological factors underlying the climate trends contributing to water deficit was conducted to promote awareness and strategic planning. Since 1980, global greenhouse gases have risen $2 \mathrm{ppm} \cdot \mathrm{yr}^{-1}$, South Africa's industrial emissions exceeded

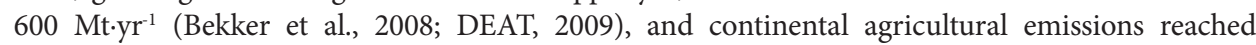
$1350 \mathrm{Mt} \cdot \mathrm{yr}^{-1}$ (Semazzi and Song, 2001; Sinha et al., 2003). This study focuses on the mesoscale structure of the drying trend, with equal focus on winter rain and summer desiccation.

\section{DATA AND METHODS}

The region near Cape Town, South Africa (SA), has a dense network of rainfall, streamflow and potential evaporation stations maintained by the Department of Water and Sanitation (DWS). Here monthly long-term records with $>90 \%$ completeness are obtained in the Upper Berg River catchment for the period $1956-2017$ for 3 stations with near-continuous records: $33.65^{\circ} \mathrm{S}, 19.01^{\circ} \mathrm{E} ; 33.83^{\circ} \mathrm{S}$, $19.08^{\circ} \mathrm{E} ; 33.93^{\circ} \mathrm{S}, 19.06^{\circ} \mathrm{E}$ (positions shown in Fig. 2b). High resolution NOAA MODIS (cf. Table 1 acronyms) satellite data were analysed for land surface temperature and vegetation colour (2000-2017), to study both climate and land-use impacts. The dispersion of urban emissions is represented by OMI satellite $\mathrm{NO}_{2}$ measurements (Bucsela et al., 2013) averaged for 2010-2017. Gridded fields that have been generated by interpolation of station measurements since 1901 include: CRU4 rainfall and Palmer Drought Severity Index (PDSI; Harris et al., 2014) and GPCC7 rainfall (Schneider et al., 2014). Modern data assimilation of in-situ and satellite observations provide datasets starting in 1979: CHIRPS2 rainfall (Funk et al., 2015); NCEP2 atmosphere reanalysis (Kanamitsu et al., 2002); NOAAv2 sea surface temperature (SST; Reynolds et al., 2007), NOAA net outgoing long-wave radiation (OLR; Lee 2015), MERRA2 atmosphere reanalysis (Reinecker et al., 2011; Molod et al., 2015), and SODA3 ocean reanalysis since 1980 (Carton and Giese, 2008). Table 1 lists the datasets, resolution and starting dates employed herein. Wells et al. (2004) and Vicente-Serrano et al. (2010) describe how the CRU4 PDSI is formulated from station measurements of standardized precipitation minus potential evaporation anomalies. Here the PDSI in the area, $34.5-33.5^{\circ} \mathrm{S}, 18.5-19.5^{\circ} \mathrm{E}$, is used to calculate trends by linear regression, as in Jury $(2013,2018)$. The rate of change or slope is evaluated across the field (for maps and sections) and within the study area (for time series) using parameters derived from reanalysis: wind circulation, air- land- sea-temperature, humidity, rainfall and vegetation. Statistical evaluations used the Pearson's 2-tailed t-test and degrees of freedom (DF). For records covering the period 1980-2017, the $\mathrm{DF}=37$ so $90 \%$ confidence is achieved when the correlation coefficient $r>|0.27|$ or $r^{2}>0.06$. Otto et al. (2018) employ similar datasets and statistical analyses to evaluate the drying trend.

The DWS hydrology analyses are conducted by averaging streamflow and (A-pan) potential evaporation data at the three stations in the Upper Berg River catchment (1956-2017), then filtering
CORRESPONDENCE

Mark R Jury

EMAIL

mark.jury@upr.edu

\section{DATES}

Received: 22 July 2019

Accepted: 8 June 2020

\section{KEYWORDS}

Cape Town

climate trend

water deficit

\section{COPYRIGHT}

() The Author(s)

Published under a Creative Commons Attribution 4.0 International Licence (CC BY 4.0) 
Table 1. Datasets used in the trend analysis. References are listed in text; web sources are: IRI Climate Library (2018), KNMI Climate Explorer (2018), APDRC Hawaii (2018), DWS (2018) and Wundermap (2018)

\begin{tabular}{|c|c|c|}
\hline Acronym & Name and variables & $\begin{array}{l}\text { Resolution } \\
\text { Start year }\end{array}$ \\
\hline CHIRPS2 & $\begin{array}{l}\text { Climate hazards infrared precipitation } \\
\text { with station v2 (Meteosat + gauge) }\end{array}$ & $\begin{array}{l}5 \mathrm{~km} \\
1981\end{array}$ \\
\hline CRU4 & $\begin{array}{l}\text { Climate Research Unit v4 } \\
\text { (gauge-based, PDSI, rainfall) }\end{array}$ & $\begin{array}{c}50 \mathrm{~km} \\
1901\end{array}$ \\
\hline DWS & $\begin{array}{l}\text { Dept of Water and Sanitation station data } \\
\text { for streamflow and potential evaporation }\end{array}$ & $\begin{array}{l}1 \mathrm{~km} \\
1956\end{array}$ \\
\hline GPCC7 & $\begin{array}{l}\text { Global Precipitation Climatology Center } \\
\text { V7 (gauge-based) }\end{array}$ & $\begin{array}{c}50 \mathrm{~km} \\
1901\end{array}$ \\
\hline MERRA2 & $\begin{array}{l}\text { Modern Era Reanalysis for Research and } \\
\text { Applications v2 (model-based) } \\
\text { case study meteorology U V W T q }\end{array}$ & $\begin{array}{c}60 \mathrm{~km} \\
1980\end{array}$ \\
\hline MODIS & $\begin{array}{l}\text { Moderate Imaging Sensor (satellite) } \\
\text { land surface IR temperature } \\
\text { color vegetation fraction }\end{array}$ & $\begin{array}{l}1 \mathrm{~km} \\
2000\end{array}$ \\
\hline NCEP2 & $\begin{array}{l}\text { National Center for Environmental } \\
\text { Prediction v2 Reanalysis (model-based) } \\
\text { U V W wind circulation trends }\end{array}$ & $\begin{array}{c}180 \mathrm{~km} \\
1979\end{array}$ \\
\hline NOAA & $\begin{array}{l}\text { National Oceanic and Atmospheric } \\
\text { Administration (satellite data) } \\
\text { sea surface temperature (SST)* } \\
\text { net outgoing longwave radiation (OLR) }\end{array}$ & $\begin{array}{c}25 \mathrm{~km}^{*} \\
100 \mathrm{~km} \\
1980\end{array}$ \\
\hline OMI & $\begin{array}{l}\text { Ozone Monitoring Instrument } \\
\text { (AURA satellite) v3 }\end{array}$ & $\begin{array}{c}25 \mathrm{~km} \\
2010\end{array}$ \\
\hline SODA3 & $\begin{array}{l}\text { Simple Ocean Data Assimilation v3 (model- } \\
\text { based ocean reanalysis) }\end{array}$ & $\begin{array}{c}50 \mathrm{~km} \\
1980\end{array}$ \\
\hline
\end{tabular}

with an 18-month low-pass filter to remove seasonal cycles. The DWS time-series are then comparable with the filtered CRU4 PDSI precipitation minus potential evaporation anomalies. To achieve a mesoscale perspective on climate change, high-resolution products of limited record length are utilized. However multi-year variability may affect the results and requires evaluation. This is done by wavelet spectral analysis, and by cropping the PDSI time series at various start dates, and recalculating the linear regression slope and explained $\left(r^{2}\right)$ variance.

Ranking the satellite land surface temperature, a hot dry spell of 1-8 January 2011 was analysed using MERRA reanalysis fields and South African Weather Service hourly observations and radiosonde profiles from Cape Town airport (CPT). The case study helps link the Cape Town regional hydrology with climate change from rising greenhouse gases, amid natural multi-year fluctuations (Poccard et al., 2000).

The method for detecting trends, using linear regression and its $r^{2}$ fit, is a simple approach that contributes to robust interpretations. One issue is the constraint of record length that depends on technological advances: (i) station rainfall since 1900, (ii) streamflow since 1950, (iii) satellite data since 1980, and (iv) highresolution data since 2000. This issue is resolved by comparison of the longest record (PDSI) in those same eras.

\section{RESULTS}

\section{Cape Town regional and spatial trends}

Cape Town's urban $\mathrm{NO}_{2}$ emissions (Fig. 1a) illustrate the atmospheric impact of 4 million residents and their resource needs (cf. Sousa et al., 2018). Higher pollution concentrations at $33.75^{\circ} \mathrm{S}, 18.75^{\circ} \mathrm{E}$ extend northward in a broad arc, according to OMI satellite measurements averaged 2010-2017. Values $>10 \mu \mathrm{g} \cdot \mathrm{m}^{-3}$ are consistent with in-situ data (Western Cape Government, 2017). The wind and rainfall trend map 1981-2017 (Fig. 1b) illustrates a broad cyclonic circulation trend and drying over the Cape Flats $\left(31-34^{\circ} \mathrm{S}, 18-19^{\circ} \mathrm{E}\right)$ which lie northwest of the Hottentots Holland mountains.
SST trends (Fig. 1c) are positive offshore but negative nearshore (cf. Rouault et al., 2010), and point to the intensification of coastal upwelling by south-easterly winds from 1981-2017. The offshore Ekman transport and cyclonic wind shear lifts cool water over the shelf and strengthens the Benguela Current, with a desiccating effect as seen below.

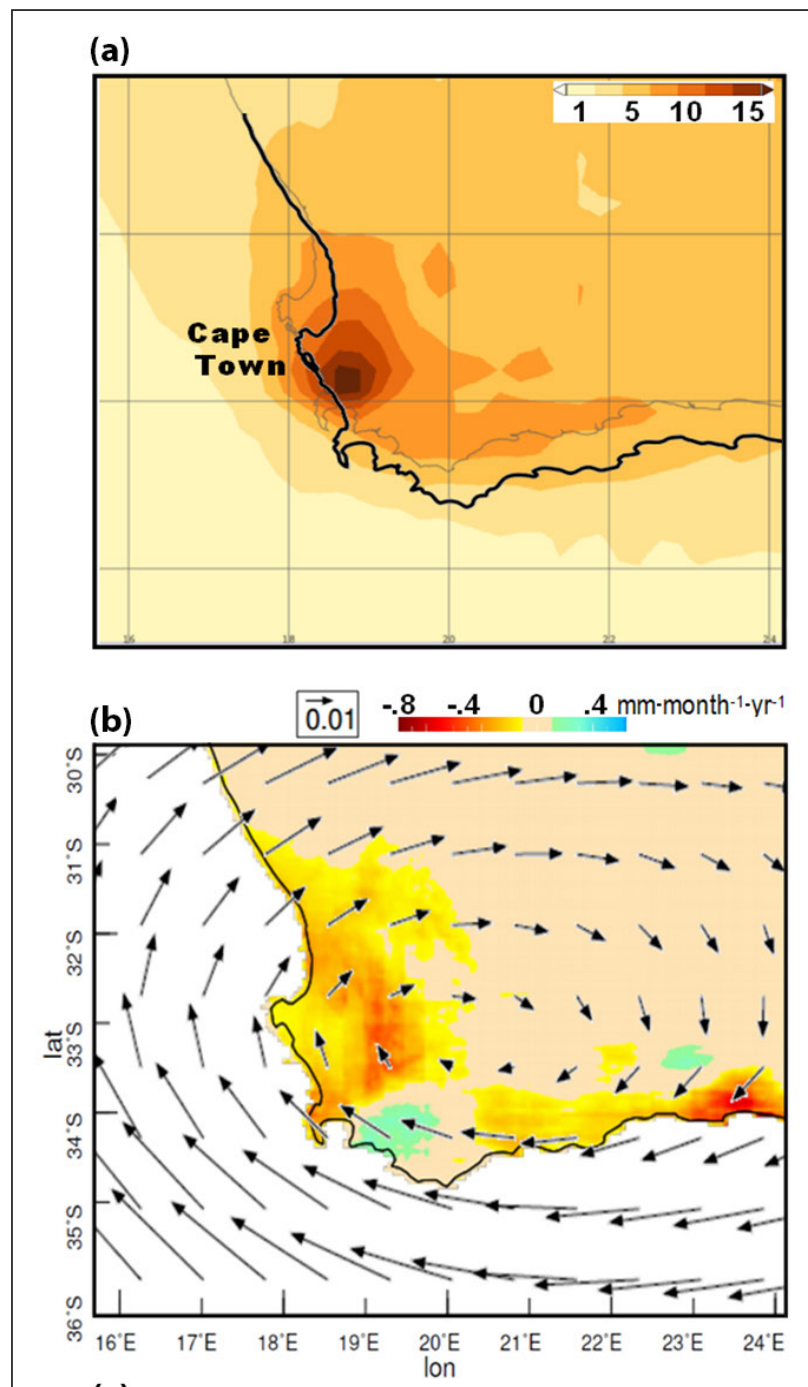

(c)

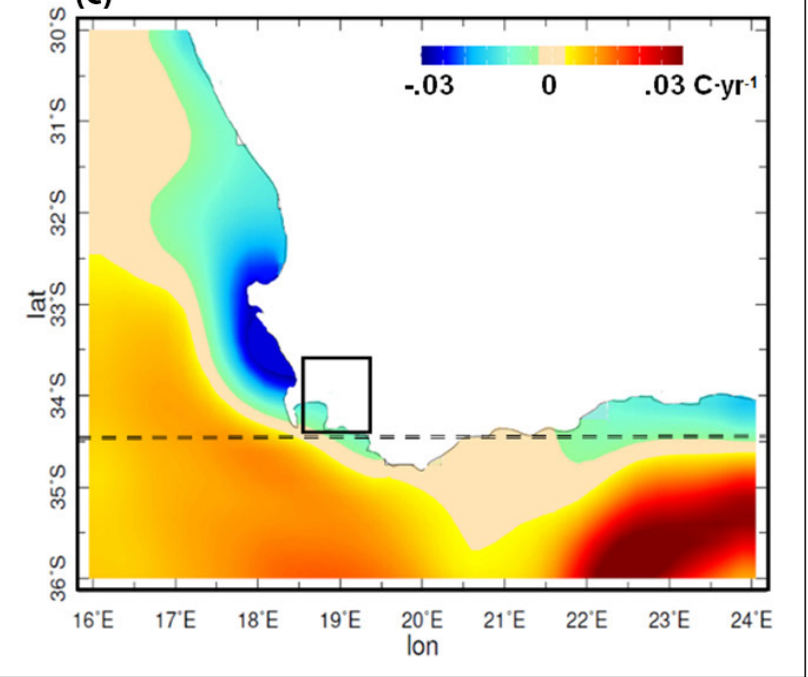

Figure 1. (a) 2010-2017 average $\mathrm{OMI}$ satellite $\mathrm{NO}_{2}$ concentration illustrating urban emissions $\left(\mu \mathrm{g} \cdot \mathrm{m}^{-3}\right)$. The 1981-2017 linear trend of: (b) $1000-925 \mathrm{hPa}$ NCEP2 wind vectors $\left(\mathrm{m} \cdot \mathrm{s}^{-1} \cdot \mathrm{yr}^{-1}\right)$ and CHIRPS2 rainfall (shading), (c) NOAA v2 SST. These maps cover the Cape Town region; the square in (c) is the 'study area' used in temporal analysis Fig. 3; the dashed line in (c) refers to vertical section Fig. 4. 
Land surface temperatures in the period 2000-2017 (Fig. 2c) display increases of $0.1^{\circ} \mathrm{C} \cdot \mathrm{yr}^{-1}$ according to $1 \mathrm{~km}$ resolution MODIS infra-red data. Values are highest at the Berg River Dam, built in 2008 near Franschhoek $\left(0.2^{\circ} \mathrm{C} \cdot \mathrm{yr}^{-1}\right), \sim 10$ times above global and national means (Kruger and Shongwe, 2004). Such a high rate of warming is related with construction of the dam followed by water receding around its perimeter, and subsequent heating of bare soil during periods of high solar radiation (Appendix, Fig. A1; cf. Earth observatory 2018). In conjunction, the vegetation colour fraction has declined in the mountain catchments (Fig. 2d), around the water reservoirs $\left(-0.02 \cdot \mathrm{yr}^{-1}\right)$, and over the Cape Flats urban area. A lower vegetation fraction gives off less transpired moisture. In contrast, 'greening' is noted in the MODIS era (2000-2017) to the east of the Hottentots Holland $>19.1^{\circ} \mathrm{E}\left(+0.01 \cdot \mathrm{yr}^{-1}\right)$, where
CHIRPS2 rainfall trends (1981-2017) are weakly positive (Fig. 2e) due to up-slope easterly winds (cf. Fig. 4e).

The main hydrological concern is the diminishing rainfall northwest of the Hottentots Holland, across the populated Cape Flats. The annual rain trend is $-0.5 \mathrm{~mm} \cdot \mathrm{month}^{-1} \cdot \mathrm{yr}^{-1}$ in the vicinity of Wellington $\left(33.64^{\circ} \mathrm{S}, 19.00^{\circ} \mathrm{E}\right)$. The histogram of NOAA infrared vegetation temperature, comparing the 1982-1988 and 2010-2016 era (Fig. 2f), illustrates shifts in both cold and warm seasons. In the $12.5^{\circ} \mathrm{C}$ range typical of winter, there was a reduction from 18 to 12 months. In the $30-32.5^{\circ} \mathrm{C}$ range typical of summer, there was an increase from 3 to 24 months. The histogram indicates a rapidly warming summer climate, which is placed in context below. The reader is referred to Fig. A2 (Appendix) for a comparison of PDSI trends over different record lengths.
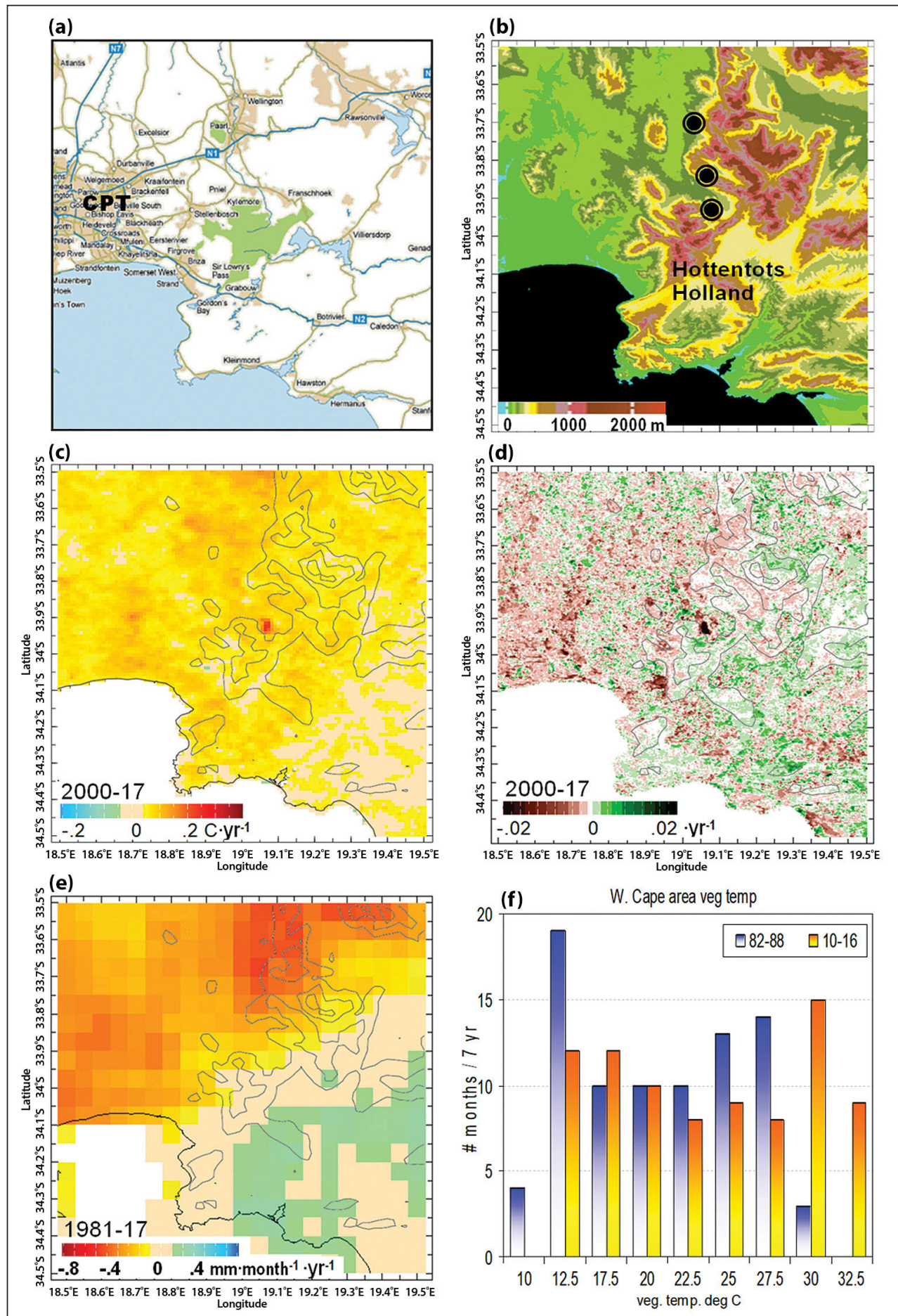

Figure 2. The SW Cape study area: (a) urbanization and geography, (b) topography and $3 \times$ DWS stations, (c) MODIS 1 km surface temperature trend (2000-2017), (d) MODIS $1 \mathrm{~km}$ vegetation fraction trend (2000-2017), (e) CHIRPS2 $5 \mathrm{~km}$ rainfall trend (1981-2017), (f) histogram of NOAA satellite vegetation temperature averaged in the study area: \# months per bin $\left({ }^{\circ} \mathrm{C}\right)$ in the first versus last 7 years. 


\section{Temporal characteristics}

In this section, a temporal analysis is presented for station observations in the study area (cf. Fig. 2a,b). Ensemble rainfall trends per month since 1901 (Fig. 3a) are downward in most months, especially in May and September, at the beginning and end of winter. Filtered streamflow and potential evaporation anomalies in the Upper Berg River catchment since 1956 (Fig. 3b) reveal significant drying trends, with $r^{2}$ variance of $31 \%$ and $41 \%$, respectively. The downward slope of filtered streamflow anomalies is $-0.012 \mathrm{~m}^{3} \cdot \mathrm{s}^{-1} \cdot \mathrm{month}^{-1}$; while the upward slope of filtered potential evaporation anomalies is $+0.020 \mathrm{~W} \cdot \mathrm{m}^{-2} \cdot \mathrm{month}^{-1}$. Streamflows nearly ceased by 2017 (end of record).

The filtered CRU4 PDSI anomalies since 1901 (Fig. 3c) reveal a persistent downward trend through the $20^{\text {th }}$ century, consistent with Wolski, (2018). The 1970s saw a prolonged dry spell that recurred in the most recent decade (2010+). Apart from the 1950s and 1980s, the surface water balance has shown deficit conditions: potential evaporation exceeded precipitation. The downward trend in PDSI is 17\% of total variance (1901-2017).

Multi-year variability is evaluated by wavelet spectral analysis in Fig. 3d. A persistent 11-year period is found from 1930 to 1980 . This cycle fades out and is replaced by a $\sim 5$-year oscillation. Sousa et al. (2018) show how the Southern Hemisphere circulation affects moisture flows, producing multi-year variability around the drying trend.

The filtered PDSI record is cropped at various start dates to assess the influence of multi-year variability on linear trends in Fig. A2 (Appendix). Starting in 1956: the slope is -0.0023 and $r^{2}$ variance $12 \%$; cropped from 1980: the slope is -0.0082 and variance is $55 \%$; and cropped from 2000 the slope is -0.0116 and variance is $41 \%$.
Both linear slope and variance intensify, suggesting that multiyear variability is gradually overshadowed by trends attributable to climate change.

The above-mentioned station-based results are supported by satellite net OLR data averaged over the study area (Table 2) segregated by month. Positive trends that refer to reduced cloud cover are most significant in the December to April months (1979-2017). A similar analysis of MERRA zonal winds (not shown) found significantly increased surface easterly winds in December, January and April.

Table 2. Trends in satellite net OLR averaged over the study area 34.5-33.5S, 18.5-19.5E, expressed as the Pearson-product correlation between the linear slope and the time series, per month in the period 1979-2017. Positive $r$-values refer to reduced cloud cover.

\begin{tabular}{lcc}
\hline Months & $r$-value & $p$-value \\
\hline January & 0.646 & 0.000 \\
February & 0.406 & 0.009 \\
March & 0.381 & 0.015 \\
April & 0.573 & 0.000 \\
May & 0.214 & 0.192 \\
June & 0.206 & 0.208 \\
July & 0.441 & 0.005 \\
August & 0.396 & 0.013 \\
September & 0.461 & 0.003 \\
October & 0.408 & 0.010 \\
November & 0.322 & 0.045 \\
December & 0.508 & 0.001 \\
\hline
\end{tabular}

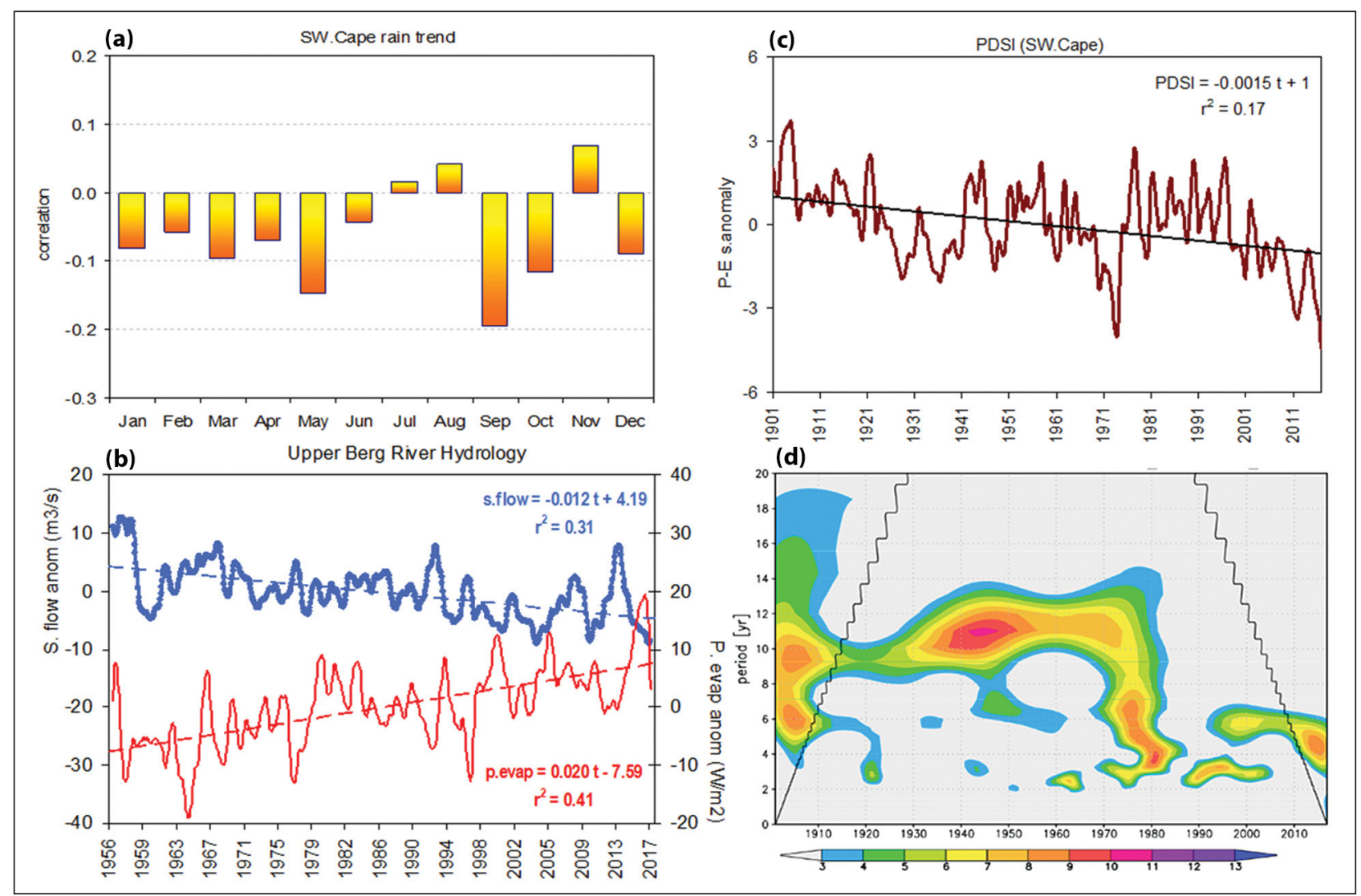

Figure 3. (a) Bar-chart of temporal correlation of SW Cape rainfall with linear trend, per month, average of three datasets (1901+), (b) time-series of DWS data averaged in the Upper Berg River catchment (cf. Fig 2b): streamflow and potential evaporation anomalies after smoothing with 18-month low-pass filter (1956+), (c) time-series of CRU4 PDSI representing filtered precipitation minus potential evaporation anomalies (1901+) averaged in the study area $\left(34.5-33.5^{\circ} \mathrm{S}, 18.5-19.5^{\circ} \mathrm{E}\right)$, and (d) its wavelet spectra illustrating significant periods of multi-year variability. Trends and variance are listed (in b, c), anomalies are offset in (b) for clarity. 


\section{Regional features associated with the drying trend}

Trends are mapped in vertical sections along $34^{\circ} \mathrm{S}$ from $15.5^{\circ} \mathrm{E}$ to $24.5^{\circ} \mathrm{E}$ in Fig. $4 \mathrm{a}-\mathrm{d}$. A surprising result is that subsident trends within the easterlies are strongest south of the Langeberg mountains $\left(20-24^{\circ} \mathrm{E}\right)$. Air temperature trends are relatively weak at $0.01^{\circ} \mathrm{C} \cdot \mathrm{yr}^{-1}$ in the $1000-900 \mathrm{hPa}$ layer. Warming increases westward, consistent with a change from moistening $21-24^{\circ} \mathrm{E}$ to drying $16-19^{\circ} \mathrm{E}$. Botai et al. (2017) found a similar east-west pattern in their trend analyses.

Turning attention to the shelf oceanography, it is evident that upwelling has intensified $\left(-0.02^{\circ} \mathrm{C} \cdot \mathrm{yr}^{-1}\right)$ from surface to $40 \mathrm{~m}$ depth to the east of $19^{\circ} \mathrm{E}$, despite a warming trend elsewhere in the period 1980-2016. The warm air/cool sea trend causes sensible heat flux $(\mathrm{Qh})$ to decline at $-0.2 \mathrm{~W} \cdot \mathrm{m}^{-2} \cdot \mathrm{yr}^{-1}$. Hence the lower atmosphere is stabilized along the South Cape coast. As a secondary consequence, the subsidence inversion strengthens and caps the surface easterly flow, as outlined in Jury and Reason (1989). The Froude number, calculated from $F=U / N H$, offers a way to determine whether the airflow will ascend the SW Cape mountains $(F \geq 1)$ or go around them $(F<1)$. With a westerly wind of $U=10 \mathrm{~m} \cdot \mathrm{s}^{-1}$, a mountain height of $H=10^{3} \mathrm{~m}$, and a winter-time unstable $(\mathrm{d} \theta / \mathrm{d} z)$ lapse rate of $N=\left(\left(\mathrm{g} \theta_{\mathrm{o}}\right)(\mathrm{d} \theta / \mathrm{dz})\right)^{0.5} \sim 10^{-2} \mathrm{~s}^{-1}$, the airflow lifts over the mountains causing stratiform rainfall. Under the summer-time easterly wind regime, the $U$ and $H$ values remain; but SST cooling and low-level warming (eg. $-Q h$ ) induce a stablelapse rate of $N \sim 2 \cdot 10^{-2} \mathrm{~s}^{-1}$, so $F=0.5$. The marine airflow is diverted around the mountains instead of going over the Hottentots Holland; leaving them sunny and prone to desiccation.

As the sub-tropical ridge shifts poleward, there is a broad zone of intensifying easterly flow from $32-40^{\circ} \mathrm{S}$ and $0-40^{\circ} \mathrm{E}$ (Fig. 4e), in agreement with Sousa et al. (2018). Evidence of Venturi acceleration at the southern tip of Africa $\left(35^{\circ} \mathrm{S}, 20^{\circ} \mathrm{E}\right)$ emerges in zonal wind trends of $-0.05 \mathrm{~m} \cdot \mathrm{s}^{-1} \cdot \mathrm{yr}^{-1}(1980-2017)$. The associated easterly shear spins-up a wind rotor over the SW Cape (cf. Fig. 1b) with desiccating consequences.

The clockwise curvature of easterly winds can be traced to three influences: firstly, the change in coastal orientation, secondly, the daytime thermal gradient/sea-breeze and, thirdly, the landfriction/Ekman spiral. Seabreeze forcing is: $\mathrm{d} V=((g H / \theta) \mathrm{d} \theta / \mathrm{d} y)$ $\mathrm{d} t$ with $g=$ gravity, $H=$ surface layer $\sim 30 \mathrm{~m}$, potential temperature $\theta \sim 300 \mathrm{~K}, \mathrm{~d} \theta \sim 3 \mathrm{~K}$ sea-land temperature increase, and $\mathrm{d} y, \mathrm{~d} t$ are length and time scales (both $\sim 2 \times 10^{4}$ ). The Ekman spiral effect is: $V=U g\left(e^{-\mathrm{az}} \sin (-a z)\right)$, with $U g$ geostrophic easterly wind $\left(\sim 10 \mathrm{~m} \cdot \mathrm{s}^{-1}\right)$, $a=(f / 2 \mathrm{~K})^{0.5}, z=30 \mathrm{~m}$, coriolis $f=710^{-5} \mathrm{~s}^{-1}$, and terrestrial eddy viscosity $K>2 \mathrm{~m}^{2} \cdot \mathrm{s}^{-1}$. As the easterly winds turn equatorward near Cape Town, subsidence is generated: $W=V(\Delta Z)(\beta / f)$, with $V \sim 5$ $\mathrm{m} \cdot \mathrm{s}^{-1}$, thickness $\Delta Z \sim 3 \times 10^{3} \mathrm{~m}, \beta=\mathrm{df} / \mathrm{dy} \sim-1.510^{-11} \mathrm{~s}^{-1} \cdot \mathrm{m}^{-1}$, and $f=710^{-5} \mathrm{~s}^{-1}$. Sinking motion of $W \sim-3 \times 10^{-3} \mathrm{~m} \cdot \mathrm{s}^{-1}$ actively dries out the lower atmosphere. The regional pattern of zonal wind anomalies for Dec-Jan 2011 (Fig. 4f) is consistent with the longterm trend (negative over Cape Agulhas, cf. Fig. 4e), and leads into a case study dry spell.

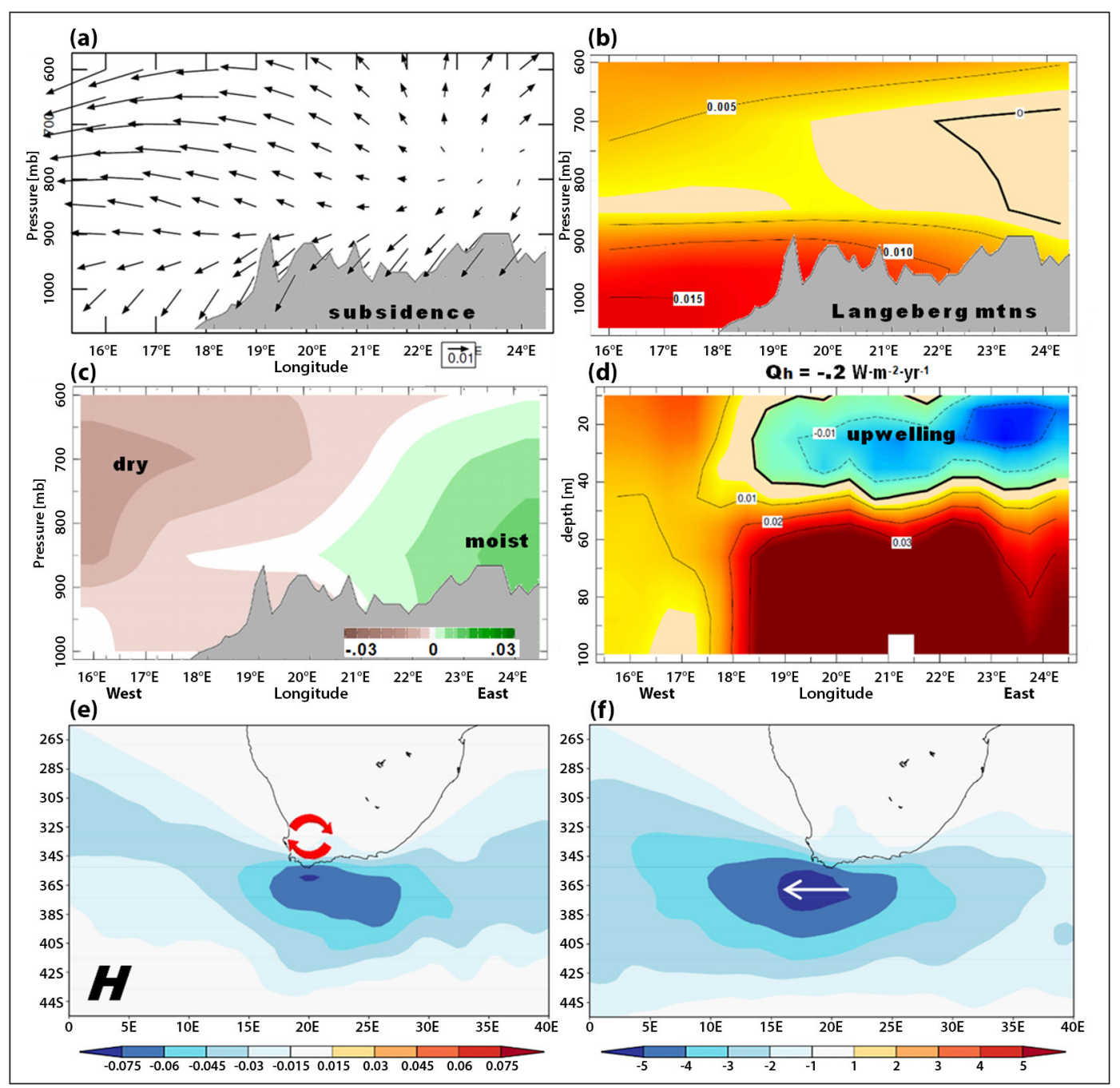

Figure 4. Trend in vertical section west-east averaged in SW Cape latitudes $\left(33.5-35^{\circ} \mathrm{S}\right)$ of (a) zonal circulation (vectors $U, W$ ), (b) air temperature $\left({ }^{\circ} \mathrm{C} \cdot \mathrm{yr} \mathrm{r}^{-1}\right),(\mathrm{c})$ specific humidity (ppt.yr $\left.\mathrm{r}^{-1}\right)$, and (d) sub-surface sea temperature $\left({ }^{\circ} \mathrm{C} \cdot \mathrm{yr} \mathrm{r}^{-1}\right)$; extending from $15.75^{\circ} \mathrm{E}$ to $24.5^{\circ} \mathrm{E}(1980+)$ with topography profile. (e) Dec-Jan trend of MERRA surface zonal wind (1980+) $\mathrm{m} \cdot \mathrm{s}^{-1} \cdot \mathrm{yr}^{-1}$ and (f) surface zonal wind anomaly in Dec-Jan $2011 \mathrm{~m} \cdot \mathrm{s}^{-1}$. Qh (between b, d) = trend of sensible heat flux over the coastal upwelling zone. The SW Cape rotor is depicted in (e). 


\section{Dry spell case study}

Ranking the MODIS daytime land surface temperature record in the SW Cape $\left(33.5-34.5^{\circ} \mathrm{S}, 18.5-19.5^{\circ} \mathrm{E}\right)$, the period $1-8$ January 2011 is the hottest case $\left(42^{\circ} \mathrm{C}\right)$ in the period $2000-2017$. The map of surface temperatures (Fig. 5a) reveals a narrow strip of cool conditions along the windward coastal promontories such as Cape Point $\left(20^{\circ} \mathrm{C}\right)$. However, across the Cape Flats and interior valleys (Berg, Breede) the daytime land surface temperatures exceed $50^{\circ} \mathrm{C}$ ! The airflow at $850 \mathrm{hPa}$ (Fig. 5b) shows cyclonic curvature and $>5$ $\mathrm{m} \cdot \mathrm{s}^{-1}$ easterlies over the ocean to the south. The vegetation colour fraction (Fig. 5c) diminished by 0.1 from the end of December to mid-January 2011 in the Upper Berg River catchment, west of the Hottentots Holland mountains. A vertical section analysis shows a strong easterly 'jet' capped by an inversion (Fig. 5d) in the period 1-8 January 2011 . In the offshore zone $\left(35^{\circ} \mathrm{S}\right)$, the near-surface winds were $10 \mathrm{~m} \cdot \mathrm{s}^{-1}$ and temperatures were $<20^{\circ} \mathrm{C}$. During this dry spell, offshore ocean transport and coastal upwelling caused significant cooling over the shelf, evidenced by SST $<15^{\circ} \mathrm{C}$ (Fig. 5e). A consequence of warm air overlying cool sea is thermal stability, which inhibits the inland penetration of moisture (cf. Fig. 5b). The CPT weather station reported desiccating weather conditions for 3-6 January (Fig. 5f), characterized by $\operatorname{Tmax}=34^{\circ} \mathrm{C}$ and Tdew $=16^{\circ} \mathrm{C}$. Southerly winds strengthened for 3-4 January to $35 \mathrm{~km} \cdot \mathrm{h}^{-1}$, and then abated following passage of the South Atlantic high pressure cell. CPT radiosonde profiles on 6 January 2011 (Table A1, Appendix) describe characteristics in the 400-700 $\mathrm{m}$ subsidence inversion: wind direction/speed $110^{\circ} / 14 \mathrm{kn}$, temperature $32.6^{\circ} \mathrm{C}$, dewpoint $-14.6^{\circ} \mathrm{C}$, and specific humidity $1.36 \mathrm{~g} \cdot \mathrm{kg}^{-1}$, due to entrainment of dry air from aloft (cf. $500 \mathrm{hPa}$ sinking motions in Fig. 5e). Many DWS stations near Wellington recorded potential evaporation $>12 \mathrm{~mm} \cdot \mathrm{day}^{-1}$ !

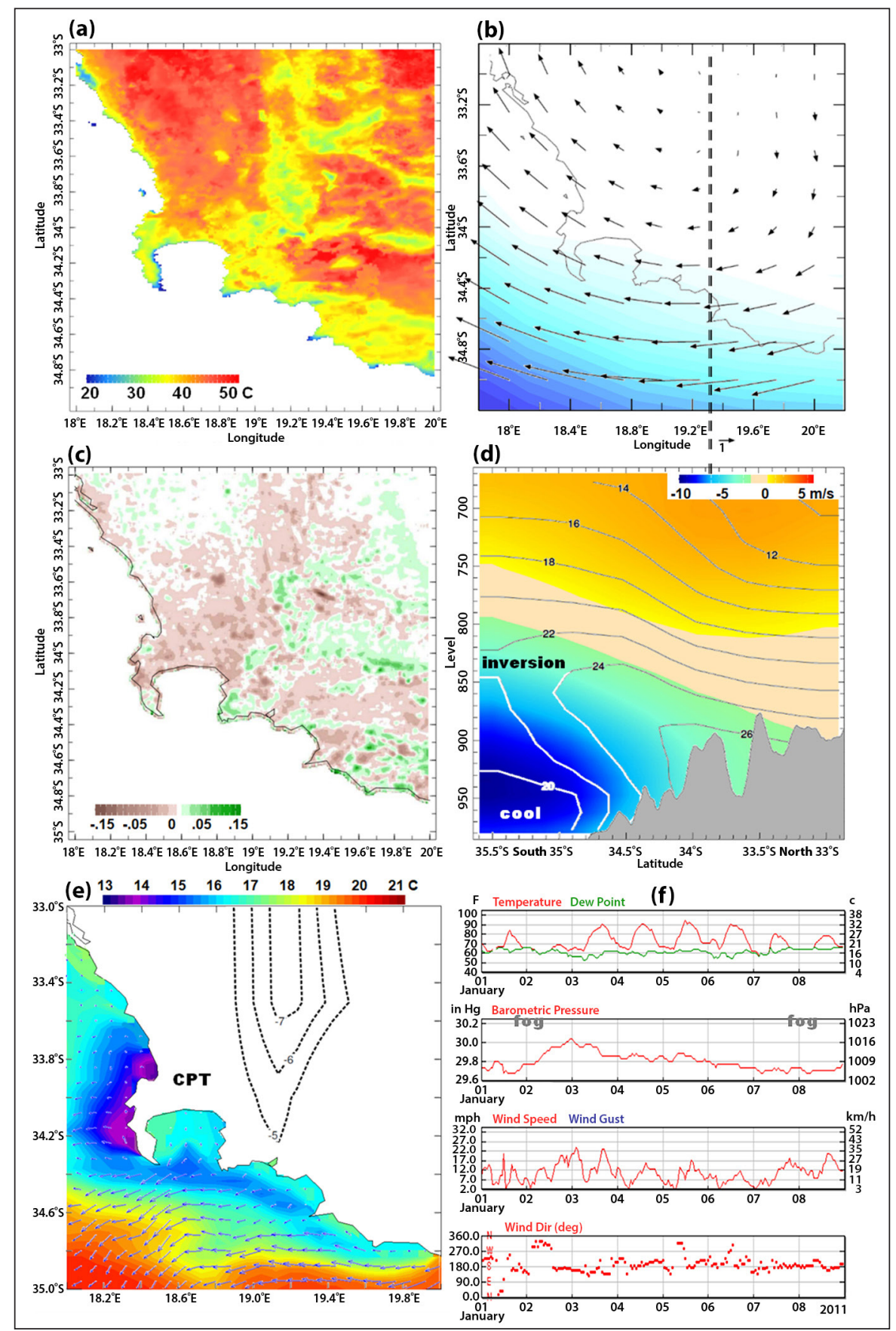

Figure 5. Case study of hot dry weather for 1-8 Jan 2011, (a) daytime land surface temperature, (b) $850 \mathrm{hPa}$ wind vectors and latent heat flux (blue shading 5-50 W. $\mathrm{m}^{-2}$ ), (c) change in vegetation fraction from before to after the dry spell. (d) Vertical section on $19.33^{\circ} \mathrm{E}$, dashed line in (b), of MERRA zonal wind (shaded) and air temperature (contour) with topography profile; (e) MODIS $1 \mathrm{~km}$ sea surface temperature, SODA surface currents (blue vectors max $1 \mathrm{~m} \cdot \mathrm{s}^{-1}$ ) and $500 \mathrm{hPa}$ vertical motion (dashed contours $\times 10^{-3} \mathrm{~m} \cdot \mathrm{s}^{-1}$ ), (f) hourly weather (SAWS-METAR) observations at CPT airport during the dry spell. 


\section{SUMMARY}

Hydro-climate trends near Cape Town, South Africa, were studied using historical observations since 1901, and gridded reanalysis fields and satellite observations since 1979. Trends (slope) were determined by linear regression and its $r^{2}$ fit. This simple approach led to objective interpretations of a drying trend, regardless of record length. Hydrology station measurements in the Upper Berg River catchment since 1956 reveal a downward slope in filtered streamflow anomalies of $-0.012 \mathrm{~m}^{3} \cdot \mathrm{s}^{-1} \cdot \mathrm{month}^{-1}$, and an upward slope in filtered potential evaporation anomalies of $+0.020 \mathrm{~W} \cdot \mathrm{m}^{-2} \cdot \mathrm{month}^{-1}$. Rainfall has declined most in May and September, indicating a shortening of the winter wet season. Multi-year variability has little effect on filtered PDSI trends in different periods: slopes are consistently downward $(-0.0015$ to $-0.0116 \cdot$ month $\left.^{-1}\right)$ and explained variance remains significant (12-55\%; cf. Fig. A2, Appendix). Despite the steadiness of drying, the variety of datasets and record lengths poses limitations.

The drying trend near Cape Town was associated with a poleward shift of the sub-tropical ridge, more frequent easterly winds, and a longer summer dry season. The easterly winds have secondary consequences: increased south coast upwelling and low-level subsidence over the Hottentots Holland (cf. Fig. 4a, c). The wind shear induces a cyclonic rotor around Cape Town which entrains dry air from the Karoo interior. Precipitation has declined particularly northwest of the Hottentots Holland mountains and many water reservoirs show diminishing inflows, increased surface temperature $\left(+.1^{\circ} \mathrm{C} \cdot \mathrm{yr}^{-1}\right)$ and browning of nearby vegetation since 2000. The easterly winds derive from a zone of negative sensible heat flux over coastal upwelling, so the capping inversion (cf. Fig. 5d, Table A1, Appendix) inhibits orographic cloud development.

The regime shift from mid-latitude westerly winds and winter rainfall, to sub-tropical easterly winds and summer dry spells, has depleted water resources (Otto et al., 2018). Hence recycling, desalination, importation, and aquifer extraction projects are underway (Patel, 2018), and water conservation has become rooted in popular thinking and community awareness. The above results contribute to this educational initiative, and suggest that water scarcity in Cape Town, South Africa, will require ongoing vigilance.

\section{ACKNOWLEDGEMENTS}

South African Department of Education SAPSE funding support is acknowledged.

\section{REFERENCES}

APDRC HAWAII (2018) URL: http://apdrc.soest.hawaii.edu/las86/ (Accessed 17 May 2018).

BEKKER B, EBERHARD A, GAUNT T and MARQUARD A (2008) South Africa's rapid electrification programme: Policy, institutional, planning, financing and technical innovations. Energ. Polic. 36 3125-3137. https://doi.org/10.1016/j.enpol.2008.04.014

BOTAI CM, BOTAI JO, DE WIT JP, NCONGWANE KP and ADEOLA AM (2017) Drought characteristics over the Western Cape Province, South Africa. Water. 9 876. https://doi.org/10.3390/w9110876

BUCSELA EJ, KROTKOV NA, CELARIER EA, LAMSAL LN, SWARTZ WH, BHARTIA PK, BOERSMA KF, VEEFKIND JP, GLEASON JF and PICKERING KE (2013) A new stratospheric and tropospheric $\mathrm{NO}_{2}$ retrieval algorithm for nadir-viewing satellite instruments, applications to OMI. Atmos. Meas. Tech. 6 2607-2626. https://doi. org/10.5194/amt-6-2607-2013

CARTON JA and GIESE BS (2008) A reanalysis of ocean climate using Simple Ocean Data Assimilation (SODA). Mon. Weather Rev. 136 2999-3017. https://doi.org/10.1175/2007MWR1978.1

DEAT (Department of Environmental Affairs and Tourism, South Africa) (2009) Greenhouse gas inventory of South Africa: 19902000. Pretoria.

DWS (Department of Water and Sanitation, South Africa) (2018) URL: http://www.dwa.gov.za/Hydrology/ (Accessed 22 May 2018).
EARTH OBSERVATORY (2018) Satellite photos. www.earthobservat ory.nasa.gov/IOTD/view.php?id=91649 (Accessed April 2018).

FUNKCC, PETERSON PJ, LANDSFELD MF, PEDREROSDH, VERDIN JP, ROWLAND JD, ROMERO BE, HUSAK GJ, MICHAELSEN JC and VERDIN AP (2014) A quasi-global precipitation time series for drought monitoring: U.S. Geol. Surv. Data Ser. 8324 pp. https://doi. org/10.3133/ds832

HARRIS I, JONES PD, OSBORN TJ and LISTER DH (2014) Updated high-resolution grids of monthly climatic observations, the CRUv4 Dataset. Int. J. Climatol. 34 623-642. https://doi.org/10.1002/joc. 3711

IRI CLIMATE LIBRARY (2018) URL: https://iridl.ldeo.columbia.edu/ sources/ (Accessed 7 May 2018).

JURY MR and REASON CJ (1989) Extreme subsidence in the AgulhasBenguela air mass transition. Bound. Layer Meteorol. 46 35-51. https://doi.org/10.1007/BF00118445

JURY MR (2013) Climate trends in southern Africa. S. Afr. J. Sci. 109 53-63. https://doi.org/10.1590/sajs.2013/980

JURY MR (2018) Climate trends across South Africa since 1980. Water SA 44 297-307. https://doi.org/10.4314/wsa.v44i2.15

KANAMITSU M, EBISUZAKI W, WOOLLEN J, YANG S, HNILO JJ, FIORINO M and POTTER GL (2002) NCEP-DOE AMIP-II Reanalysis (R-2). Bull. Am. Meteorol. Soc. 83 1631-1643. https://doi. org/10.1175/BAMS-83-11-1631(2002)083<1631:NAR>2.3.CO;2

KNMI CLIMATE EXPLORER (2018) URL: http://climexp.knmi.nl/ (Accessed 12 May 2018).

KRUGER AC and SHONGWE S (2004) Temperature trends in South Africa: 1960-2003. Int. J. Climatol. 24 1929-1945. https://doi.org/ 10.1002/joc.1096

KRUGER AC and NXUMALO MP (2016) Surface temperature trends from homogenized time series in South Africa: 1931-2015. Int. J. Climatol. 37. https://doi.org/10.1002/joc.4851

LEE H-T (2014) Climate algorithm theoretical basis document: Outgoing long-wave radiation (OLR). NOAA's Climate Data Record (CDR) Program, CDRP-ATBD-0526. 46 pp.

MACKELLAR N, NEW M and JACK C (2014) Observed and modelled trends in rainfall and temperature for South Africa: 1960-2010. S. Afr. J. Sci. 110 1-13. https://doi.org/10.1590/sajs.2014/20130353

MITCHELL TD and JONES PD (2005) An improved method of constructing a database of monthly climate observations and associated high-resolution grids. Int. J. Climatol. 25 693-712. https:// doi.org/10.1002/joc.1181

MORISHIMA W and AKASAKA I (2010) Seasonal trends of rainfall and surface temperature over Southern Africa. Afr. Stud. Monogr. 40 67-76.

MOLOD A, TAKACS L, SUAREZ M and BACMIESTER J (2015) Development of the GEOS-5 atmospheric general circulation model: evolution from MERRA to MERRA2. Geosci Model Dev. 8 13391356. https://doi.org/10.5194/gmd-8-1339-2015

MUlleR M (2017) Understanding Cape Town's Water Crisis. Civil Engineering June 2017. https://ssrn.com/abstract=2995937. 11-16.

OTTO FEL, WOLSKI P, LEHNER F, TEBALDI C, VAN OLDENBORGH GJ, HOGESTEEGER S, SINGH R, HOLDEN P, FUCKAR NS, ODOULAMI RC and NEW M (2018) Anthropogenic influence on the drivers of the Western Cape drought 2015-2017. Environ. Res. Lett. 13124010.

PATEL M (2018) Desalination in South Africa: panacea or peril for industrial development? URL: www.tips.org.za/research-archive/ sustainable-growth/item/3500-desalination-in-south-africapanacea-or-peril-for-industrial-development. $41 \mathrm{pp}$.

POCCARD I, JANICOT S and CAMBERLIN P (2000) Comparison of rainfall structures between NCEP/NCAR reanalyses and observed data over tropical Africa. Clim. Dyn. 16 897-915. https://doi.org/ 10.1007/s003820000087

REYNOLDS RW, SMITH TM, LIU C, CHELTON DB, CASEY KS and SCHLAX MG (2007) Daily high-resolution blended analyses for sea surface temperature. J. Clim. 20 5473-5496. https://doi. org/10.1175/2007JCLI1824.1

RIENECKER MM, SUAREZ MJ, GELARO R, TODLING R, BACMEISTER J, LIU E, BOSILOVICH MG, SCHUBERT SD, TAKACS L, KIM G and co-authors (2011) MERRA: NASA's modern-era retrospective analysis for research and applications. J. Clim. 24 3624-3648. https://doi.org/10.1175/JCLI-D-11-00015.1 
ROUAULT M, POHL B and PENVEN P (2010) Coastal oceanic climate change and variability from 1982 to 2009 around South Africa. Afr. J. Mar. Sci. 32 237-246. https://doi.org/10.2989/1814232X.2010.501563

SCHNEIDER U, BECKER A, FINGER P, MEYER-CHRISTOFFER A, ZIESE M and RUDOLF B (2014) GPCC's new land surface precipitation climatology based on quality-controlled in situ data and its role in quantifying the global water cycle. Theor. Appl. Climatol. 115 15-40. https://doi.org/10.1007/s00704-013-0860-x

SEMAZZI FHM and SONG Y (2001) A GCM study of climate change induced by deforestation in Africa. Clim. Res. 17 169-182. https:// doi.org/10.3354/cr017169

SINHA P, HOBBS PV, YOKELSON RJ, BERTSCHI IT, BLAKE DR, SIMPSON IJ, GAO S, KIRCHSTETTER TW and NOVAKOV T (2003) Emissions of trace gases and particles from savanna fires in southern Africa. J. Geophys. Res. 108 d13, 8487. https://doi. org/10.1029/2002JD002325

SOUSA PM, BLAMEY RC, REASON CJC, RAMOS AM and TRIGO RM (2018) The 'Day Zero' Cape Town drought and the poleward migration of moisture corridors. Environ. Res. Lett. 13124025. https://doi.org/10.1088/1748-9326/aaebc7
TADROSS M, JACK C and HEWITSON B (2005) On RCM-based projections of change in southern African summer climate. Geophys. Res. Lett. 32 L23713. https://doi.org/10.1029/2005GL024460

VICENTE-SERRANO SM, BEGUERIA S, LOPEZ-MORENO JL, ANGULO $\mathrm{M}$ and ElKENAWY A (2010) A new global $0.5^{\circ}$ gridded dataset (1901-2006) of a multiscalar drought index: comparison with current drought index datasets based on the Palmer Drought Severity Index. J. Hydrometeorol. 11 1033-1043. https://doi.org/10. 1175/2010JHM1224.1

WELLS N, GODDARD S and HAYES MJ (2004) A self-calibrating Palmer drought severity index. J. Clim. 17 2335-2351. https://doi. org/10.1175/1520-0442(2004)017<2335:ASPDSI>2.0.CO;2

WESTERN CAPE GOVERNMENT (2017) State of Environment Outlook Report for the Western Cape Province. Air quality. November 2017. http://ward2forum.org/wp-content/uploads/2017/ 11/W_Cape_SOER_08_Air_Quality.pdf

WOLSKI P (2018) How severe is Cape Town's 'Day Zero' drought? Significance 15 24-27. https://doi.org/10.1111/j.1740-9713.2018.01127.x WUNDERMAP (2018). https://www.wunderground.com/wundermap (Accessed 22 May 2018). 


\section{APPENDIX}

Table A1. CPT radiosonde significant-level data up to $850 \mathrm{hPa}$ during case study, with inversion, berg winds (upper) and dry layer (lower) in bold

\begin{tabular}{|c|c|c|c|c|c|c|}
\hline \multicolumn{7}{|c|}{6 Jan $20110 Z$} \\
\hline Pressure (hPa) & Geopot. Ht. (m) & Air Temp. $\left({ }^{\circ} \mathrm{C}\right)$ & Dewpoint Temp $\left({ }^{\circ} \mathrm{C}\right)$ & S.humidity $\mathbf{g} \cdot \mathbf{k g}^{-1}$ & Wind Direct $\left(^{\circ}\right)$ & Wind speed (kn) \\
\hline 850 & 1518 & 25 & -1 & 4.2 & 155 & 16 \\
\hline 877 & 1243 & 27 & 2 & 5.07 & 138 & 15 \\
\hline 925 & 771 & 30.2 & 6.2 & 6.47 & 110 & 14 \\
\hline 931 & 713 & 30.8 & 6.8 & 6.7 & 114 & 14 \\
\hline 962 & 420 & 32.6 & 6.6 & 6.39 & 135 & 11 \\
\hline 968 & 364 & 32.2 & 7.2 & 6.62 & 139 & 11 \\
\hline 974 & 309 & 30.8 & 8.8 & 7.35 & 143 & 11 \\
\hline 986 & 200 & 26.2 & 12.2 & 9.13 & 151 & 10 \\
\hline 997 & 102 & 25.2 & 13.2 & 9.65 & 158 & 9 \\
\hline 1000 & 76 & 24 & 15 & 10.83 & 160 & 9 \\
\hline 1004 & 42 & 22.2 & 16.2 & 11.67 & 220 & 10 \\
\hline \multicolumn{7}{|c|}{6 Jan $20119 Z$} \\
\hline 850 & 1558 & 24 & -6 & 2.89 & 205 & 12 \\
\hline 909 & 968 & 29.4 & -14.6 & 1.36 & 201 & 10 \\
\hline 925 & 813 & 30.4 & -13.6 & 1.45 & 200 & 9 \\
\hline 938 & 689 & 31.4 & -10.6 & 1.83 & 207 & 8 \\
\hline 944 & 632 & 31 & -1 & 3.78 & 210 & 8 \\
\hline 950 & 576 & 29 & 6 & 6.21 & 214 & 8 \\
\hline 962 & 465 & 26.6 & 11.6 & 8.99 & 220 & 7 \\
\hline 991 & 202 & 28 & 13 & 9.58 & 235 & 5 \\
\hline 1000 & 122 & 28.6 & 12.6 & 9.24 & 240 & 5 \\
\hline 1003 & 95 & 29.2 & 12.2 & 8.97 & 257 & 6 \\
\hline 1009 & 42 & 32.2 & 7.2 & 6.35 & 290 & 7 \\
\hline
\end{tabular}

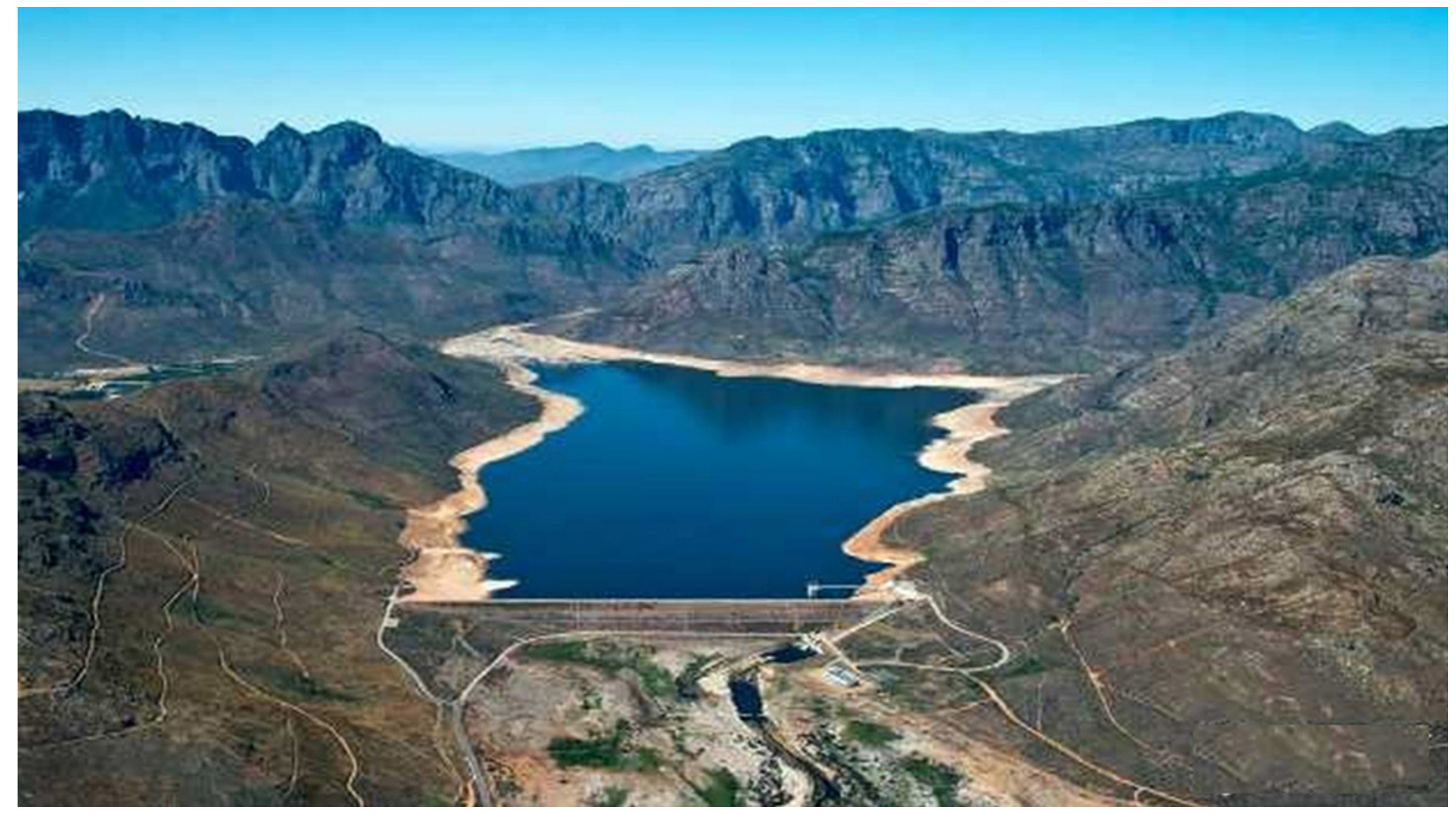

Figure A1. Aerial photo by Jean Tresfon, of the Berg River Dam near Franschoek (33.90 $\left.\mathrm{S}, 19.06^{\circ} \mathrm{E}\right)$ in early 2018 , showing desiccation on the perimeter 


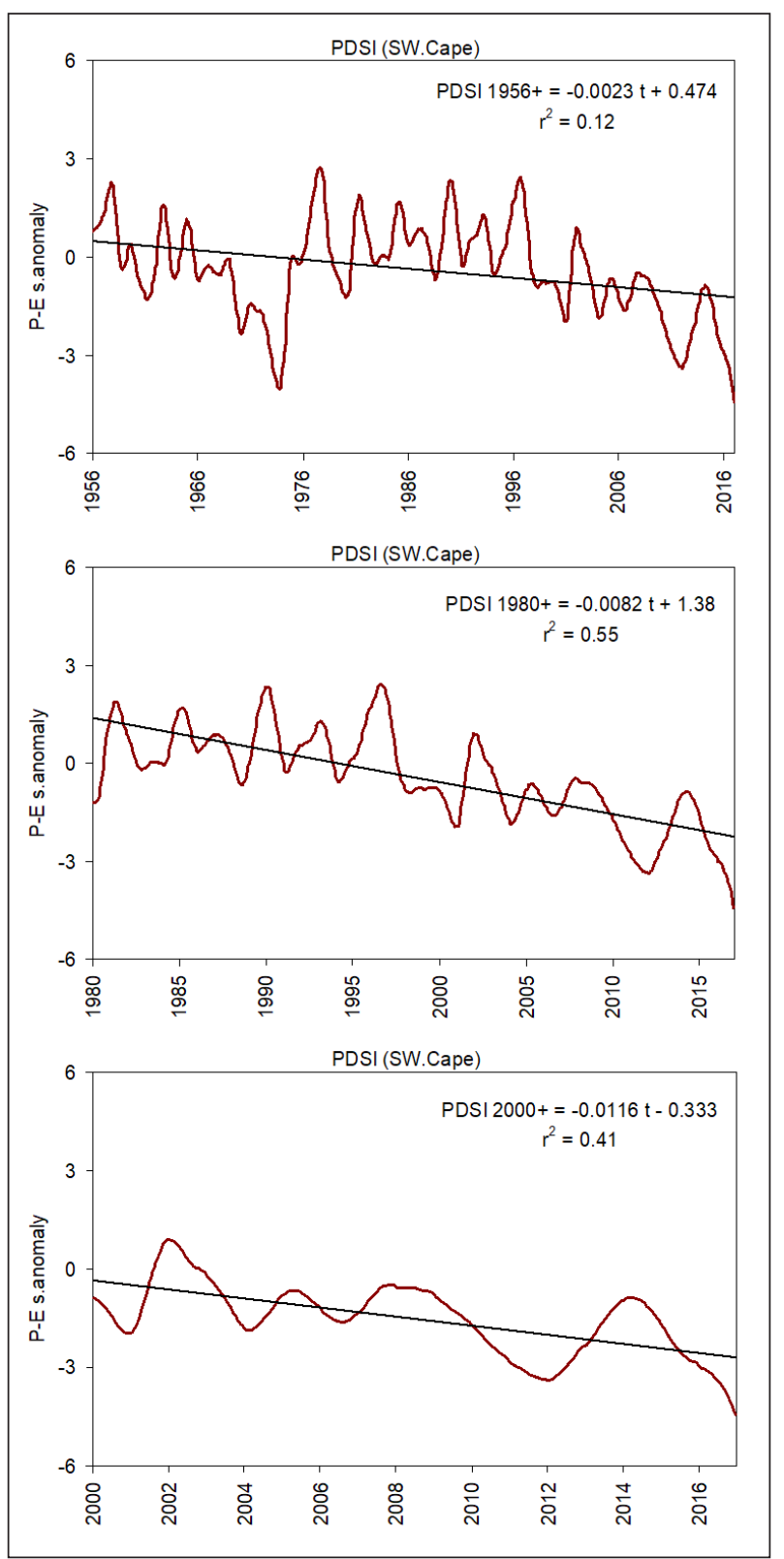

Figure A2. Analysis of filtered PDSI temporal trends and variance explained by linear regression, distinguished by starting year (top-down: 1956+, 1980+, 2000+); for comparison with other temporal analyses 